\title{
A note from the President
}

\author{
José J. G. Moura
}

(C) SBIC 2010

\section{The Society of \\ Biological Inorganic Chemistry}

SBIC has been established as a learned society of advanced research and education in the field of Biological Inorganic Chemistry

\section{SBIC COUNCIL}

\section{President}

José J.G. Moura, Lisbon, Portugal

\section{Past President}

Trevor Hambley, Sydney, Australia

\section{Secretary}

Charles Riordan, Newark, DE, USA

\section{Treasurer}

Graeme Hanson, St. Lucia, Australia

\author{
Members \\ Victoria A. DeRose, Berkeley, CA, USA \\ Julia A. Kovacs, Seattle, WA, USA \\ Janet R. Morrow, Amherst, NY, USA \\ Stephen W. Ragsdale, Ann Arbor, MI, USA \\ Britt-Marie Sjöberg, Stockholm, Sweden \\ Paola Turano, Florence, Italy \\ Alejandro J. Vila, Rosario, Argentina
}

\author{
Chief Editor of JBIC \\ Lawrence Que Jr., Minneapolis, MN, USA \\ Program Committee/ICBIC-IOC \\ Kenneth D. Karlin, Baltimore, MD, USA \\ Nominations Committe \\ Lucia Banci, Florence, Italy \\ SBIC Website: \\ http://SBIChem.org
}

This is the last issue of JBIC in 2010. The year that ends celebrated the Biodiversity in the planet-Biodiversity in life and in our lives. The year to come, 2011, celebrates the International Year of Chemistry (IYC 2011, http://www.chemistry2011.org/). Chemistry is in our lives, every day and everywhere.

Bioinorganic Chemistry provides a relevant bridge between these two events. As a newcomer to the chemical sciences and in the interface with life sciences, this discipline brought to the scene the importance of metal ions in biology and their interaction with proteins. Proteins that contain metals represent about one third of known proteins. Multiple functions have been described. Transport and homeostasis are important processes under critical observation. Interaction of (metallo)proteins with other proteins and other cellular components has been a key issue for the understanding of regulation and specificity. The field introduced a new approach to the study of complex systems and has explored experimental (using sophisticated instrumentation) and theoretical approaches.

This journal is the mirror of the vitality and multiple interests of our community. It is our responsibility to transmit to the scientific community, and in particular to the general public, the importance of metals in biology and make recognizable the wide range of fields where our contributions have a large impact, namely environment, medicine, agriculture, nutrition, energy, and many others. It is important to publicize news of the achievements of chemistry and its contributions to the well-being of humankind. Under the unifying theme "Chemistry—our life, our future," IYC 2011 will offer a range of interactive, entertaining, and educational activities for all ages. The Year of Chemistry is intended to reach across the globe, with opportunities for public participation at the local, regional, and national level (as indicated by the United Nations, UNESCO and IUPAC).

Let's celebrate Bioinorganic Chemistry.

Let's celebrate Chemistry.

Let's make an effort to explain, in simple words, the impact and relevance of our knowledge and our tools.

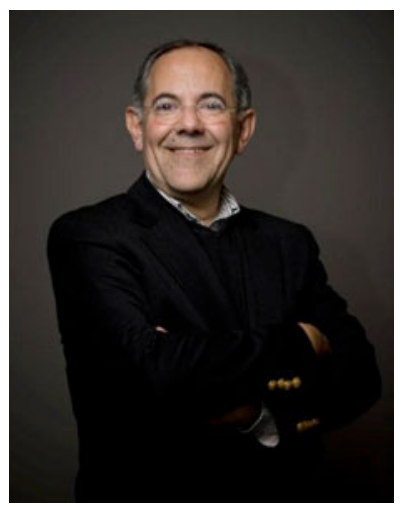

José J. G. Moura 